\title{
Má význam bránit „neproduktívne“ vzdelávacie obsahy v dnešných časoch?
}

\author{
Zuzana DanišKová
}

Jedným z prejavov oslabovania pozornosti k učivu vo vyučovaní je značne vábivý dôraz na mäkké zručnosti, a s tým súvisiaca kumulácia textov tematizujúca okrem nich aj klúčové kompetencie. Tie sa však medzičasom stali univerzálnym zaklínadlom. Pupala (2004) kedysi satiricky poznamenal, že záverečné a kvalifikačné práce sa predbiehajú $\mathrm{v}$ tom, ktorá ponúkne humanistickejšiu podobu vyučovania - dnes môžeme vyslovit podobný súd aj o kompetenciách či zručnostiach adorovaných na rôznych úrovniach pedagogického diskurzu. Existujú však aj varovania, ktoré upozorňujú na takéto následné sploštenie poslania školy. Autori potom metaforicky školu prirovnávanú $\mathrm{k}$ učilištu, $\mathrm{k}$ továrni, $\mathrm{k}$ prípravke pracovných síl pre kapitál, či $\mathrm{k}$ pobočke súkromného sektora (napr. Rybák, 2012). Týmto textom sa pokúšame ukázat opodstatnenost' „neproduktívnych“ vzdelávacích obsahov a pomôct' tým rehabilitovat netriviálnost' a významnost' formálneho školského kurikula. Pokúšame sa sumarizovat', prepojit' a pripomenút argumenty, ktoré nachádzame roztrúsené na rôznych miestach, pričom práve téma obsahov vzdelávania ich navzájom prepája.

\section{Obsahy PRE OtVORENIE NÁHL'ADU}

Najčastejší argument, ktorý zaznieva $\mathrm{v}$ prospech reformy obsahov, je poukazovanie na ich zastaranost a nepotrebnost' s odôvodnením iných spoločenských podmienok. Ak sa pozrieme na rôzne vládne, ale i mimovládne stratégie, ktoré chcú udávat tón d’alšiemu vývoju v oblasti vzdelávania, je možné sa presvedčit', že formulované obavy nad vytrácaním obsahov nie sú žiadnym akademickým rojčením. Často sa opakuje nedostatok rozvoja mäkkých zručností, prílišná akademickost́ predmetov, neprimeranost teoretizovania na úkor aplikácií a prepojení na prax. Každá epocha v sebe nesie zmeny voči minulosti, kedy sú jedny idey vystriedané inými - nejde však v tomto prípadě o falošnú argumentáciu, ktorá modernostou a „novostou“ zakrýva pragmatickost' a utilitarizmus vzdelávania, ako ho popísala už Arendtová (1994)? Tieto determinujú filozofiu vzdelávania a spôsobujú to, čo dnes nazýva Scruton $(2005$, s. 156) „revolúciou relevancie“ - kedy sa o významnosti toho, čo sa v škole učí, uvažuje 
výsostne $\mathrm{v}$ spojitosti $s$ bezprostrednou užitočnostou. ${ }^{1} \mathrm{Na}$ druhej strane však možno pripustit, že tvorcovia vzdelávacích politík ${ }^{2}$ nevedia posúdit a demaskovat ideové pozadie svojich návrhov, vdaka ktorým poznanie $^{3}$ nie je cenené pre jeho inherentnú hodnotu, ale sa o ňom uvažuje ako o jednom $\mathrm{z}$ výrobných faktorov. $\mathrm{V}$ tomto prípade je už reč o intelektuálnom kapitále, pričom sa podnikatel'ský prístup podla Jarvisa (Jarvis in Kopecký et al., 2013) s tým akademickým navzájom absolútne míña - poznanie aj učenie sa pestuje najmä procesuálne, sledujúc schopnost' „opúštat naučené a používané $\mathrm{v}$ prospech niečoho nového" (tamže, s. 96).

Ako však nájst' správnu mieru medzi transmisívnostou a frontálnostou, povrchnou encyklopedickostou bez aktívnej pozície intelektu a pragmatickým kompetenčným modelom? Inšpiratívne sa nám $\mathrm{v}$ tomto smere javí uvažovanie J. Fialy (1993, 2000a, 2000b, 2004, 2013), ktorý tento modus vivendi nachádza.

Základným východiskom, ktoré následne determinuje celú argumentáciu, je chápanie vzdelania. J. Fiala na viacerých miestach odmieta definovat vzdelanie ako niečo, čo vlastníme. Nie je možné si ho kúpit' ani predávat', pretože predmetom obchodu môže byt' len to, čo je výsledkom školenia (získavanie schopností pre určité zamestnanie, napr. vediet ostrihat psa, obsluhovat počítač, vyriešit diferenciálnu rovnicu). Vzdelanie nemôžeme mat', ale môžeme byt vzdelaní. Vzdelanie nie je čo, ale je to ked'... Vzdelanie nie je poznanie faktov, ale nie sú to ani zručnosti, napr. ako fakty vyhladávat', najmä ak nevieme, čo máme hladat a prečo. Fiala poznamenáva, že práve toto je najzávažnejším nedostatkom - učíme sa fakty a informácie ako typické odpovede, pričom však nepoznáme položené otázky a samozrejme nerozumieme tomu, prečo by sme mali niečo také vediet'. Tento nedostatok ho však neprivádza do situácie, v ktorej odmietne zastúpenie obsahov. Základná otázka neznie čo sa má učit, ale „čo ostane, ak sa to všetko zabudne"(2004, s. 70). Bez látky, obsahu, faktov, bez toho $\check{c}$, to nemá zmysel - čo musí byt' konkrétne vysvetlené a vyučované, ale napriek tomu, a to je najvýraznejšia a najinšpiratívnejšia Fialova myšlienka, nezáleží na tom, čo bude tvorit toto $\check{c} o$.

Nie je potrebné odprezentovat' „celú látku predmetu“, ktorá ostane „mítvymi listami na hladine rybníka"(Bergson, 1939 , s. 42), ale vybrat niekol'ko miest a zostat pri nich tak dlho, pokial' sa neotvorí svet matematiky, literatúry

\footnotetext{
${ }^{1}$ Sledovat relevanciu vo vzdelávaní je chiméra - je možné dnes povedat', čo bude relevantné v kontexte záujmov žiaka o niekol'ko rokov?

${ }^{2}$ Je pomerne zložité pomenovat túto skupinu ludí jednoznačnejšie, pretože dnes sa odborníkom na vzdelávanie, ktorý dostane možnost participovat na tvorbe politík, môže stat rovnako vážne akademik, ako aj učitel's dlhoročnou praxou, či absolvent všeobecného odboru verejnej politiky majúci skúsenosti s prácou v l'ubovol’nom think tanku. Kombinácia ekonóma a experta verejnej politiky produkuje následne dokumenty adorujúce zručnosti a kompetencie bez ohl'adu na matériu. Avšak domnievame sa, že práve takýto experti a odborníci priamo svojou prácou dokazujú scestnost vlastnenia zručností bez ohladu na obsah, ktoré je možné flexibilne aplikovat'. ${ }^{3} \mathrm{Na}$ tomto mieste by český pojem védění vystihol omnoho viac, ale slovenčina jeho obdobu nepozná.
} 
či dejepisu. ${ }^{4}$ Toto otvorenie svetov sa deje cez vel'mi konkrétne fakty - inak by $\mathrm{k}$ tomu neprišlo, ale na nich samotných nezáleží. Nie je postačujúce svety rôznofarebne a vyčerpávajúco popísat', je potrebné $\mathrm{v}$ nich pobývat', aj ked' len chvílu a nie nevyhnutne $\mathrm{v}$ hlavnom meste pre prežitie krásy, inakosti, tajomstva. Táto cesta nie je priamočiarym procesom a treba ju zahájit včas, lebo ak sa otvorenie neuskutoční v pravú chvílu, už nikdy nemá šancu. Nie je pravdou, že ak toho naučíme málo, budú toho málo vediet - malé príčiny môžu mat' vel'ké následky. Preto je úlohou učitel'a a školy dat možnost́ preniknút do ducha predmetu, umožnit stretnutie, dotyk a vstupom do týchto svetov ukázat na jednej strane ich odlišnosti a krásu, ale na strane druhej to, čo sa dnes zdôrazňuje často - vyvolat' iskru, túžbu, odhalit zárodok vznikajúcich dispozícií, lebo nie každému sa ukáže napr. $\mathrm{v}$ matematike, čo je $\mathrm{v}$ tom svete za vzorcami, vetami, dôkazmi. Takéto poznanie a pochopenie celku/idey neskôr umožní zoradenie a doplnenie podrobností/poznatkov, pretože ak sa to raz podarilo, existuje nádej, že sa tam $\mathrm{v}$ prípade potreby vieme vrátit.

V takto ponímanom vzdelávaní na jednej strane identifikujeme individuálne talenty a preferencie bez bezobsažných a floskulovitých diskusií o individualizácii vzdelávania, na druhej strane tento prístup produkuje aj rozvoj toho, čo má byt pred- metom školenia - zručnosti a schopnosti. Generické kompetencie sú totiž vedlajším efektom otvoreného vzdelávania, ako ho nazýva sám Fiala. Škola nemá odprezentovat' sumár encyklopedických poznatkov, ale nesmie sa ich ani vzdat a uletiet na druhú stranu soft skills, pretože „vzdelanie je schopnostou rozumiet', nikdy nie je látkou samou, ale je vždy nad látkou; nie je objektívne, ale vždy osobné, subjektívne; nie je možné ho mat'. Nie je poznaním o veciach, ale je zmyslom pre toto poznanie" (Rosenzweig in Fiala, 1993, s. 11). Fiala $\mathrm{v}$ jednom texte spomína prednášky, ktoré sa podarilo zachytit K. Čapkovi venovali sa dejinám francúzskej literatúry a prednášal ich F. X. Šalda. Dnes ich môžeme čítat v súbore jeho zväzkov pod názvom Božský rošták J. A. Rimbaud (1991). V týchto prednáškach sa Šaldovi podarilo na jednom jedinom básnikovi vysvetlit a zmapovat celé dejiny francúzskej literatúry - namiesto obsažných dejín poslucháči mohli pochopit skutočného básnika a prežit tak svet literatúry zvnútra.

\section{OBSAHY PRE PREMENU}

Prítomnost' obsahov vo vzdelávaní a špecifický spôsob ich prezentácie má potenciál vyprodukovat jedinca vzdelaného $\mathrm{v}$ duchu Rosenzweiga, môže pomôct́ identifikovat jeho individuálne nadanie a predispozície a taktiež ho vybaví potrebnými spôsobilostami, pretože tie sú nevyhnutným produktom otvoreného vzdelávania.

\footnotetext{
${ }^{4}$ Pochopenie jedného básnika alebo básne vs. celé dejiny literatúry, dianie od Keplera k Newtonovi vs. mnohoročné scientific training vo fyzike.
} 
Toto pestovanie rozumu je prvým zdôvodnením významnosti vzdelávacích obsahov. Avšak, čitatel' si zaiste uvedomil, že špecifický spôsob ich prezentácie je determinovaný istou perspektívou filozofovania o výchove. Obe je možné demonštrovat' na nasledujúcich príkladoch geometrie a matematiky.

Geometria a matematika nie sú neužitočnými a nepraktickými, a nemožno o nich povedat', že negenerujú zručnosti potrebné pre život, hoci im je pripisovaná abstraktnost' a teoretickost'. Grécka geometria je jedným z pilierov, na ktorých stojí naša kultúra, resp. racionálne poznanie. Nevznikla z praktických potrieb (Suvák, 2002), ale práve naopak - tým, že pochádza z túžby po poznaní a múdrosti, stáva sa užitočnou pri riešení praktických problémov. Pre Grékov predstavovala geometria propedeutickú prípravu vedeckého poznania a zároveň prostriedok kritického myslenia, pretože bola považovaná za jednu $\mathrm{z}$ vhodných nástrojov pre otvorenie náhladu, k získaniu evidentia - názoru; preto Platónove "nikto negeometrický nech nevstupuje". 5 To, že my o nej dnes uvažujeme ako o prílišnej teoretickej a nepraktickej disciplíne pramení zo zlej interpretácie gréckeho theória a potom sa nemožno divit' tým, ktorí by ju najradšej vypustili z obsahov vzdelávania - poznaním pre Platóna je živý náhlad idey a nie poučenie o veci bez nahliadnutia jej vnútornej povahy. Geometria teda nemá byt' scientific training, ale vhodnou príležitostou $\mathrm{k}$ získaniu názoru. ${ }^{6}$
Podobne je to aj s matematikou - Fiala (1993) vtipne parafrázuje Rosenzweiga: matematika sa učí ako dlhá anekdota bez pointy, ktorej začiatok už všetci zabudli. $\mathrm{Na}$ podobu jej vyučovania vplýva filozofia matematiky (René Thom) - ak ju učíme ahistoricky, ako manipuláciu so symbolmi, opät bude kamienkom $\mathrm{v}$ topánke. Pričom jej významnost' a využitel’nost' je $\mathrm{v}$ dnešnom svete neoddiskutovatel'ná: v rozhovore pre denník Pravda profesor matematiky K. Mikula (2016) uvádza niekol'ko príkladov, ktoré ilustrujú potrebu matematiky v rôznych odvetviach (krivka na výpočet lesného požiaru, tvorba medicínskeho softvéru, projekcia funkčnej budovy), a zároveň vyjadruje nespokojnost', že je dnes redukovaná najmä na finančnú gramotnost́. $\mathrm{Na}$ jednej strane je teda možné vidiet', že matematické vzdelanie sa očakáva v medicínskych, inžinierskych, ale aj IT profesiách, kde uchádzač rozhodne nevystačí s mäkkými zručnostami, predstieraním tých tvrdých. $\mathrm{Na}$ druhej strane, geometria môže slúžit študentom nielen humanitných odborov, tak ako kedysi slúžila filozofom. Anticipuje nielen cibrenie vnútornej energie intelektu, ale smeruje už aj k pestovaniu duše, ktorého ciel'om je premena človeka zvnútra. Tu sa vzdelávacie obsahy starajú o to, čo čítame optikou filozofie výchovy od čias gréckeho údivu a čo Fiala (2010) nazýva „podvracaním“. $\mathrm{V}$ d’alšom vývoji archetypov výchovy sa táto starostlivost́ o dušu objavuje u Komenského a oživuje ju aj Patočka.

\footnotetext{
${ }^{5}$ Viac o možnostiach geometrie a vhl'adu P. Vopěnka (2011).

${ }^{6}$ Názor nie je chápaný ako domnienka, ale ani ako ilustrácia vyučovania niečím vnímatel'ným, ale ako vhlad do určitého sveta.
} 
Duša človeka, bez ohl’adu na to, či veríme v jej smrtel'nost alebo nesmrtel'nost', je životným pohybom a vyžaduje si starostlivost', pretože má smerovat' od vonkajšieho určenia človeka, od jeho nevedomých predsudkov a bežnej situovanosti - Patočka to nazýva pohybom prijímania $\mathrm{k}$ slobode orientovanej na to, čo je „nad-situačné“ a „nad-ludské" (Palouš, 1991), k pohybu prekročenia či transcendencie ( $\mathrm{v}$ zmysle sekulárnom, nie náboženskom). Táto orientácia, resp. zásadný obrat sa uskutočňuje spôsobom, ktorý Gréci pomenúvali posvätným slovom paidea a Platón ho vysvetluje značne populárnou alegóriu $\mathrm{v}$ siedmom liste Ústavy.

Komenský rozvíja svoju vševýchovu nadviazaním na grécky koncept, pričom ju definuje ako univerzálne vzdelanie (výchova aj vyučovanie) celého ludského pokolenia smerujúce $\mathrm{k}$ náprave vecí ludských (emendatio a reparatio), pretože ludia žijú akosi „naruby“, nedbajú na to podstatné a prednost dávajú efemérnym úžitkom a pôžitkom (ako jaskynní väzni) (Komenský, 1948). Takéto poznávanie a zotrvávanie pri partikularitách však podl'a neho nezodpovedá podstate človeka, práve naopak - poznanie fragmentov má vyústit $\mathrm{k}$ poznaniu celkového zmyslu, $\mathrm{k}$ pravde celého života. V Patočkovej (2006) interpretácii toto predstavuje obrat $\mathrm{v}$ živote človeka, ktorý ho vedie od zdania $\mathrm{k}$ bytiu, od pôvodnej nepravdy $\mathrm{k}$ pravde, poriadku a ludskosti.

Patočka ešte skôr, ako číta Komenského spisy, formuluje svoju koncepciu kozmickej výchovy, ktorú nazýva pohybom pravdy. Výchova tu nie je náuka, ktorá pripravuje $\mathrm{k}$ nejakému povolaniu, alebo ovláda človeka ako manipulovatel'nú vec, či opracovaný materiál, ale akt, ktorým ide o jeho vnútornú premenu, ktorou sa stáva človekom. Vzdelávanie má človeka povznášat nad každodennost', nad „tupú normálnost"(1996, s. 367), uvádzat ho do širšieho horizontu vyšších súvislostí. Ako slobodná bytost́ nie je iba nástrojom, ktorý cibríme „drezúrou jednotlivej životnej funkcie“( s. 390), ale vzdelávaním sa $\mathrm{v}$ ňom má naplňovat́ to ludské.

Prizmou ekonómie a politiky môže byt takto postavená argumentácia čítaná ako vzletné a neužitočné rojčenie, pretože filozofické zdôvodnenia sú vyhodnocované ako zbytočné teoretické špekulácie. A $\mathrm{z}$ toho dôvodu sa musia oponenti reformných úsilí naučit formulovat námietky o to precíznejšie, pretlmočit Platónov alebo Komenského odkaz do obrazov, ktoré sú uchopitelné širším a každodennejším publikom. Vezmúc do úvahy predchádzajúce dedičstvá, obhajoba nepraktických obsahov môže byt postavená na l'udskej podstate, slobode človeka a na potrebe elít.

Už Patočka (1996) cítil, že v námietke nepotrebnosti a nepraktičnosti istých obsahov je niečo nesprávneho, nezmysluplného. Uznáva, že nie všetko v škole je účelné a vhodné pre život, ale upozorňuje, že úžitok chápeme $\mathrm{v}$ príliš úzkom význame. Užitočné je aj to, čo človeka obohacuje fyzicky aj duševne. Duševné úžitky zasahujú človeka priamo, niečo nové $\mathrm{v}$ ňom otvárajú, človek sa $\mathrm{v}$ týchto činnostiach sám vnútorne mení. Filozofické formulácie odkazujúce $\mathrm{k}$ podstate človeka, $\mathrm{k}$ nájdeniu ludskosti nie sú len záležitostou kumulo- 
vania teoretických konštruktov pozostávajúcich z rozličných pomenovaní, ale sú záležitostou „najvlastnejšieho ludského záujmu“ (Patočka, 2012, s. 70). Vztah človeka $\mathrm{k}$ poznaniu predsa determinuje jeho život, jeho činnosti v súkromí, jeho vztahy k ostatným, k obci, ako vysvetl'uje Patočka. Škola nemá učit len prostriedkom na dosahovanie určitých cielov, ale má človeka naučit „niečo vyššieho chciet" (s. 367). Potreba takéhoto bytostného vzdelania patrí $\mathrm{k}$ ludskej prirodzenosti, preto nie je vhodné „ponúkat len inštruktáž v schopnostiach manipulácie“"7 (Kratochvíl, 1995, s. 156). Tento filozofický argument nie je možné len tak lahko odbit', pretože ak neuvažujeme o vzdelávaní aj týmto spôsobom, nepotrebujeme školu, stačia nám organizácie a agentúry, ktoré budú ponúkat to, čo kedysi sofisti.

Určujúca kniha liberalizmu (Hayek, 2001) popisuje, že ak človeku nie je v dostatočnej miere ponechaný priestor (ekonomickej) slobody, stáva sa otrokom. Patočka (1996) však vo Filozofii výchovy upozorňuje, že aj bezprostredne prakticky zamerané školské vzdelávanie privádza jedinca do neslobody, kedy slúži len prostriedkom. Je nahliadaný prizmou materiálneho blaha, kedy mu je odovzdávaný ako najpodstatnejší ludský ciel' jeho budúca úspešnost́. Ciel' a zmysel jeho života tak nestojí nad ním, ale sa stáva jeho pokorným sluhom. Nesloboda človeka môže byt predsa vyjadrená aj navonok neviditel'nými okovami.

Reformy vzdelávania $\mathrm{v}$ dnešnom duchu nielenže zabúdajú na podstatu človeka a následnou redukciou ho robia neslobodným, ale môžu negatívne vplývat aj na potenciál spoločnosti generovat a formovat nové generácie elít bez ohladu na pôvod alebo majetok. "Čím menej zmyslu pre rozmanitost ludských záujmov a možností, tým tažšie musia byt dôsledky jednostrannej praktickosti a užitočnosti pre spoločnost" (Patočka, 1996, s. 437), najmä v prípade závažných celospoločenských javov. Utilitárne uvažujúci človek sa len tažko dokáže od seba odpútat́ a zaujat́ pozíciu či iné stanovisko, ktorými by formoval a kultivoval verejný priestor. Tieto očakávania vždy napíňali vzdelanci reprezentujúci elitu spoločnosti - generovali idey, určovali smerovanie alebo, ako uzatvára Liessmann (2008), rozpoznávali domnelé istoty doby ako iluzívne. Súčasný verejný priestor už zažíva situáciu pomenúvanú Fialom (2011): „o tom, čo je epistéme, rozhoduje dnes doxa".

\section{ObSAHY PRE VOL'NÝ ČAS}

Ak sa vrátime $\mathrm{k}$ zdôvodneniu potreby obsahov vzdelávania exponovaním podstaty človeka, natrafíme ešte na dalšiu súvislost', ktorú sme si pomenovali ako pestovanie vkusu. Je sýtená z perspektívy kultúry, ale zároveň preniká aj do oblasti vol'ného času človeka.

Prvú dimenziu naznačuje Strouhal (2016) sústrediac sa najmä na zastúpenie vyššej kultúry v školskom vzdelávaní, resp. na jej postupné vytrácanie sa ožitím relativistických tendencií. Je zrejmé, že k tomu-

${ }^{V}$ zmysle kompetencií. 
to javu prispieva nie malým dielom aj utilitaristický reformný diskurz. Prítomnost́ „vysokej“ kultúry vo vzdelávaní však nie je zdôvodňovaná len potrebou odovzdávat penzum kánonu spolu so schopnostou orientovat' sa v dejinnom vývoji vel'kých diel, ale aj kultiváciou indivídua povýšením ho k takým formám prežívania, ktoré by mu inak mohli ostat skryté. Zaradenie Asterixa $\mathrm{k}$ vel'kým dielam svetovej literatúry alebo prienik komiksov ${ }^{8}$ či súčasnej hudby mladých do inštitucionalizovaného školského kurikula je problematické nielen pre to, že škola týmto lacným nadbiehaním nikdy súboj $s$ aktuálnym svetom médií tam vonku nevyhrá, ale najmä preto, že musí jedincovi ponúknut možnost́ emancipovat sa od komunity, na ktorej je prirodzene závislý (Fabre in Strouhal, 2016). Strouhal píše: „Úlohou školy nie je utvrdzovat deti v tom, čo je pre ne samozrejmé, ale naopak pomáhat im prekonávat obmedzené perspektívy, z ktorých sa pozerajú na svet, najmä pokial' ide o ich schopnost́ nahliadat' to, čo je neintuitívne, ne-prirodzené, ne-užitočné a čo bežná životná realita nijak neprovokuje poznávat" (s. 68). Patočkove "niečo vyššieho chciet" teda nie je argumentom, ktorý „nahráva“ tradícii, ale naopak, stojí na strane detí a žiakov, v ktorých má škola hladat potenciál, nadanie, no zároveň ich oslobodit' od tieňov, ${ }^{9}$ urobit' $\mathrm{z}$ nich aj tvorcov kultúry, nielen konzumentov, či formovat vkus a citlivost' ku kráse (cultura animi). Je krátkozraké domnievat' sa, že žiak si nezaslúži stretnút sa so Shakespearom alebo Mozartom len preto, že to $\mathrm{v}$ jeho živote remeselníka alebo podnikatel'a nebude potrebovat' - tvorivá sila predsa môže pramenit kdekolvek.

Dimenzia vol'ného času tiež súvisí s podstatou človeka, avšak nemáme tu na mysli prostriedky vol'nočasovej výchovy, ale to, čo trefne vyjadril P. Pitha (1998): „Vzdelanost́ a vzdelanie sú zásadne potrebné najmä pre náš vol’ný čas. Zanedbávanie tejto prípravy na život sa bude čoraz viac prejavovat', a to vel'mi negatívne. Bude narastat množstvo ludí, ktorí práve nebudú mat nič na práci." Nie je to mimoškolská výchova, ale škola samotná, ktorá kultivuje náš volný čas. $V$ dávnej tradícii Grécka bol spájaný s múdrostou - ideálom života bez práce bol plný vývoj človeka po telesnej aj duševnej stránke. Bol to čas, kedy sme oslobodený od starostí a činností zabezpečujúcich základné ekonomické a životné potreby, sme naopak slobodní pre svet a jeho kultúru. Bez ohl'adu na to, či $\mathrm{v}$ dnešnej škole cítime istý sediment schóle, podstata zmyslu vol'ného času sa nezmenila. Pedagogika vníma význam vol'nočasovej výchovy vel'mi úzko, často ako prevenciu proti patologickým javom, ${ }^{10}$ avšak socio-

\footnotetext{
$\overline{8}$ Petrusek (nedat.) v eseji o umení analyzuje tzv. zmyslovú formu kultúry, pričom sa dostáva aj ku komiksom, ktoré sprostredkúvajú Foglara či Dostojevského - sociológ sa nebojí hovorit’ o infantilizácii a degenerácii. Finkielkraut (1993) hovorí o priblížení výchovy spotrebe.

${ }^{9}$ Spomínané epistéme definuje doxa: to, čo je dnes považované za kultúru, definuje masa / utilitárny/každodenný svet.

${ }^{10} \mathrm{Ak}$ aj zmieňuje sebarealizačnú funkciu, tak najmä cez aspekt uspokojovania záujmov a potrieb, nie s presahom na to, čo vyjasňuje Pieper.
} 
logický či filozofický pohlad je v mnohom plodnejší, pretože do hry vnáša aj volný čas dospelého, ktorý sa môže nudit rovnako ako dieta. Pieper (1992) vo svojej eseji vysvetluje podstatu volného času ako prestávku potrebnú nie na to, aby človek mohol pracovat dlhšie, ale aby sa $\mathrm{v}$ práci, $\mathrm{v}$ pracovnej funkcii obmedzenej na istý výňatok reality, „realizoval ako bytost', ktorá je zameraná na celok skutočnosti“ (s. 15). Prázdnota volného času je vnútorným stavom duše, uvolnením sa, odovzdaním sa, ktorá nie je určovaná objektívnou možnostou dovolenky alebo víkendu - môžeme mat vel'a vol'ného času, ale jeho priestor ostane prázdny. Vol'ný čas je časom sebazdokonalovania, prostriedkom proti duševnej hrbatosti.

Uviedli sme, že sa táto podstata vol'ného času nemení, aj ked' nie je týmto spôsobom dnes nahliadaná. V modernej spoločnosti sa totiž objavuje čosi, čo Arendtová (1994) nazýva prázdnym časom. Týmto fenoménom sa zaoberala $\mathrm{v}$ rovnakom čase, kedy premýšlala otázky výchovy a kultúry, z čoho jednoznačne vyplýva ich vzájomná súvislost́. Prázdny čas je atribútom masovej spoločnosti, ktorý sa vypĺña zábavou a spotrebou, spotrebným tovarom zábavného priemyslu - je stále časom zvyškovým, avšak je potrebné ho ukrátit. A tak utilitarizmus každodennosti, ,tyrania kalkulujúceho myslenia“" (Finkielkraut, 1993, s. 89) objavuje užitočnost neužitočného a $\mathrm{z}$ pôvodne neproduktívnych nákladov sa stáva predmet zisku. Tu sa však zabúda nielen na podstatu, o ktorej referuje Pieper, ale popiera sa aj prvá vlastnost́ vol'ného času, ktorú vymedzuje Dumazedier
(1966): volný čas oslobodzuje - nielenže je výsledkom slobodnej vol'by, ale nesie so sebou oslobodenie od (inštitucionálnych) záväzkov rôzneho druhu. Čas zábavy však nie je slobodným časom, naopak, stávame sa otrokom zábavy rovnako ako $\mathrm{v}$ čase zabezpečovania životných nutností.

Zdá sa, že tie nepraktické, od života odtrhnuté obsahy môžu v sebe skrývat d’alší potenciál: škola má umožnit dotyk $s$ transcendentujúcim umením, pretože ju $\mathrm{v}$ tom nik iný nezastúpi. Ale tento dotyk presahuje obyčajné budovanie kultúrneho vedomia - kultivuje čas ne-zaneprázdnenosti človeka a zároveň tak sprostredkúva odkaz, že zmysel bytia netkvie vo výkone profesie (najmä u ludí, ktorí nevykonávajú slobodné/tvorivé povolania). Sprostredkovaním nesamozrejmých obsahov (nielen kultúrnych) škola vystavuje jedinca vnímaniu pestrosti ludských činností a výkonov, čím zároveň determinuje bohatost jeho záujmov a úroveň jeho duchovnej prázdnoty. Vezmúc do úvahy aj stav masovej kultúry, škola môže pomôct' jedincovi rozlišití, že akákolvek zábava nemusí hned' reprezentovat kultúru, hoci je vyzdvihnutá na jej úroveň.

\section{ObSAHY PRE MORÁlKu}

Prítomnost' vysokej kultúry v školských obsahoch však okrem pestovania vkusu a súdnosti napíňa aj pestovanie vôle. Týmto posolstvom humanitných predmetov, ktoré sú statusovo zastúpené $\mathrm{v}$ školskom kurikule rôzne (nielen umením samotným), sme sa podrobnejšie zaoberali v samostatnej štúdii (Danišková, 2014). 
V krátkosti sa pokúsime vyabstrahovat základnú logiku uvažovania.

Ak sme na začiatku textu pracovali s príkladmi matematiky a geometrie, v závere textu sa pozrieme na ne-zbytočnost' humanitných obsahov prítomných $\mathrm{v}$ kurikule, pretože tieto predmety vedia suplovat etický výchovu. Už Aristoteles pri úvahách ako vychovat dobrého občana identifikuje dve oblasti - hudbu a tragédiu $(2006,2009)$ - ako prostriedky morálnej výchovy, pričom Scruton (2005) tento rozmer aplikuje širšie na celé humanitné predmety. Využíva pri tom Aristotelove poznanie, že „vediet', čo konat a čo cítit“", predstavuje praktickú múdrost', správny úsudok (orthos logos) o tom, akú emóciu je treba $\mathrm{v}$ danej chvíli vyjadrit; vycítit', čo si situácia vyžaduje. Kratochvíl (1995) pripomína, že tento typ výchovy sa $\mathrm{v}$ antike realizoval uvedením jedinca do mýtopoetickej skúsenosti napr. homérskych eposov. Toto predstavovalo kultúrnu iniciáciu, ktorá sledovala „spoločné zdiel'anie pôsobnosti reči v príbehu“ (s. 89). Mýtus tu však nepredstavuje niečo nepravdivé alebo alegorické, ale literárny žáner, ktorý človeka poúča a formuje jeho morálku.

Ak v našej perspektíve zameníme pojem mýtu za rozprávky a povesti, pochopíme ich schopnost́ ovplyvňovat charakter jedinca sprostredkovaním bohatstva ludskej skúsenosti a ludských pocitov lásky, nádeje, zmyslu bytia (Palouš, 2008). Ak novátori vyjadrujú snahu zakomponovat́ mäkké zručnosti (empatia, proaktívnost', vid. Burjan, 2017) do obsahov vzdelávania, je vhodné im pripomenút dávnu prax.
Ich pestovanie sa nemusí uskutočňovat' len výcvikom bez matérie (časté námietky voči podobe etickej výchovy), ale aj prítomnostou „mýtu“. Jeho úloha sa však naplní, ked” sa nebude učit o ňom, ale ním. O takúto rehabilitáciu narativity sa pokúsil Hábl (2013a, 2013b) demonštrujúc efektívitu príbehu ako didaktického prostriedku na interpretáciách Komenského Labyrintu. Tento prístup však nepredstavuje jednoduchý obrat v pedagogickom myslení, ako zmieňuje napr. Hník (2014) pre oblast' literárnej výchovy, a nezmení sa zvonku reformou, ale zmenou vnútra, ako vyššie deklaruje Fiala. Čítaním Shakespeara sa dozvieme, že existoval, stretneme sa s kvalitným literárnym žánrom, dotkneme sa hodnotného diela našej kultúry a najviac si odnesie fronésis.

\section{ZÁVER}

Tento text mal ambíciu ponúknut takú interpretáciu vzdelávacích obsahov, ktorá umožňuje rehabilitovat ich význam v perspektíve súčasných (pragmatických) reformných úsilí. Uvedomujeme si, ako sme uviedli na začiatku, že kritika tradičnej školy je v mnohých smeroch opravená - školou sú otrávení žiaci, unavení sú z nej učitelia. Ešte preto však nemusíme s l'ahkostou podliehat každému vábeniu sirén a vymieňat čierne za biele, pretože nový vietor môže prúdit do školy aj odinakial'. Obzretie sa a znovu premyslenie istého dedičstva našej civilizácie nám môže dodat́ dostatok sebavedomia, ktoré vedy o výchove potrebujú, stojac voči vše-valcujúcemu trendu ekonomickej racionality. 


\section{LITERATÚRA:}

Arendtová, H. (1994). Krize kultury. Praha: Mladá fronta.

Aristoteles (2006). Politika. Bratislava: Kalligram.

Aristoteles (2009). Poetika. Martin: Thetis.

Bergson, H. (1939). Milič Čapek. Praha: Nakl. Družstvo Máje.

Brouk, B. (1946). Závažnost obecného vzdělání. Praha: Václav Petr.

Burjan, V., et al. (2017). Učiace sa Slovensko. Bratislava: MŠVVaŠ SR.

Danišková, Z. (2014). Môže umenie vypestovat dobrého občana? Aristotelov príspevok vo svetle teórie výchovy. Pedagogická orientace, 24(3), 311-329.

Dumazedier (1966). Volný čas. Sociologický časopis / Czech Sociological Review, 2 (3), 443-447.

Hábl, J. (2013a). „Zčásti jinotajně, zčásti zjevně.“ Alegorie jako didaktický nástroj v Komenského Labyrintu. Paidea, 10(3), 1-12.

Hábl, J. (2013b). Učit (se) príběhem. Brno: Host.

Hayek, H. A. von (2001). Cesta do nevolníctva. Bratislava: Nadácia F. A. Hayeka.

Fiala, J. (1993). Idea školy střední. In S. Starkl, Filosofie výchovy (s. 2-18). Plzeň: Aleš Čenek.

Fiala, J. (2000a). Otevřené vzdělávaní pro otevřenou společnost. Přitomnost, 3, 18-20.

Fiala, J. (2000b). Geometrie a kritické myšlení. Literární noviny, XI(10), 5.

Fiala, J. (2004). Dělání vzdělání (dovednosti, znalosti a vzdělání). In N. Demjančuk, Univerzita v novém mileniu (s. 67-74). Plzeň: Aleš Čenek.

Fiala, J. (2010). Vzdělávaní jakožto podvracení. Vesmír, 89(10), 579.

Fiala, J. (2011). Idea univerzity dnes. Člověk v nových světech. 12. výjezdní IdS Nečtiny.

Fiala, J. (2013). Výška. Širka. Hloubka. Čas. Praha: Vize 97.

Finkielkraut, A. (1993). Destrukce myšlení. Brno: Atlantis.

Hník, O. (2014). Didaktika literatury: výzvy oboru. Praha: Karolinum.

Kratochvíl, Z. (1995). Výchova, zrejmost, vědomí. Praha: Herrmann \& synové.

Komenský, J. A. (1948). Vsevýchova. Pampedia. Praha: SNP.

Kopecký, M., et al. (2013). Védèni a učeni v globalizovaném světě: Aktéri a změny. Praha: Filozofická fakulta UK.

Liessmann, K. P. (2008). Teorie nevzdělanosti. Omyly společnosti vědení. Praha: Academia.

Mikula, K. (2016). Matematiku netreba milovat', stačí ju vediet. Pravda. Dostupné na https:// zurnal.pravda.sk/

Palouš, R. (1991). Čas výchovy. Praha: SNP.

Palouš, R. (2008). Je svět (hodnotově) dvojí nebo jeden? Paidea, 5(2).

Patočka, J. (1996). Filosofie výchovy. In Péče o duši I (s. 363-440). Praha: Oikuméné.

Patočka, J. (2006). Komenský a mathesis univerzalis. In Češi II (s. 193-212). Praha: Oikuméné. Patočka, J. (2012). Problém výchovy. Podobenství o úsečcke a o jeskyni. In Platónova péče o duši a spravedlivý stát (s. 60-72). Praha: Oikuméné.

Petrusek, M. (nedatované). Umění a životní styl ve společnosti zjitřených smyslů. Úvahy stárnoucího konzervativce. Kritika \& kontext, 16(44), 10-15. 
Pieper, J. (1992). Volný čas / vzdělání / moudrost. Praha: Křestanská akademie.

Pitha, P. (1998). O př́ipravě na život v společnosti. Prednáška na konferencii Partners in Europe: Learning Together - Building the European House of Education.

Pupala, B. (2004). Narcis vo výchove. Bratislava: Veda.

Rybák, D. (2012). Addenda k problému korupce a smyslu vzdělání. Paideia, 9(3-4), 1-13.

Scruton, R. (2005). Estetické porozumèní. Brno: Barrister \& Principal.

Strouhal, M. (2016). „Medzi Ifigenií a Asterixem“. K problematice kulturního aristokratizmu a relativizmu ve vzdělávaní. In M. Strouhal \& S. Štech (Eds.), Vzdělání a dnešek (s. 58-82). Praha: Karolinum.

Suvák, V. (2002). Úvodné poznámky k diferencii teoretického a praktického. In V. Suvák (Ed.), $K$ diferencii teoretického a praktického II (s. 7-22). Prešov: Filozofická fakulta PU.

Šalda, F. X. (1991). Šaldiov zápisnik II. Praha: Československý spisovatel'.

Vopěnka, P. (2011). Úhelný kámen evropské vzdělanosti a moci. Praha: Práh.

Mgr. Zuzana Danišková, PhD.

Trnavská univerzita v Trnave, Pedagogická fakulta, katedra školskej pedagogiky;

e-mail: zuzana.daniskova@truni.sk 